Article

\title{
Temporal Changes in Ecosystem Services in European Cities in the Continental Biogeographical Region in the Period from 1990-2012
}

\author{
Iwona Szumacher * and Piotr Pabjanek \\ Faculty of Geography and Regional Studies, University of Warsaw, Krakowskie Przedmieście 30, \\ 00-927 Warsaw, Poland; pabjanek@gmail.com \\ * Correspondence: szumi@uw.edu.pl; Tel.: +48-22-552-0755 \\ Academic Editors: Olaf Bastian and Karsten Grunewald \\ Received: 31 December 2016; Accepted: 19 April 2017; Published: 22 April 2017
}

\begin{abstract}
Ecosystem services (ES) in cities and surrounding suburban areas are one of the major factors which guarantee quality of life. Most studies directly referring to urban ecosystem services are conducted on a local scale or for selected cities. There are few studies which focus on temporal changes of the provision of ecosystem services across a large number of cities. This paper analyzes selected land use type (forest, green urban area), soil sealing, selected ecosystem services (food provisioning, climate regulation, recreation), and biodiversity potential in 85 large cities (over 100,000 citizens) from the Continental (Central and Eastern) biogeographical region in Europe. We used the Corine Land Cover (CLC) data for 1990, 2000, 2006, and 2012. Our main findings are as follows: (1) The increase of forest areas was the highest in 2006-2012, and of urban green areas in 2000-2006, mostly in cities in Germany and the western part of the Czech Republic; (2) The process of soil sealing growth occurred in all studied cities and the rate was the most intense in Polish cities; (3) There was a decrease of food production and biodiversity potential in all the analyzed cities; (4) climate regulating services experienced only slight changes; (5) There was a very positive trend of the recreation indicator in most core zones of the cities in Germany and several cities in the Czech Republic, Poland, and Denmark. Moreover, our results of the temporal changes of land use and ES in European cities in the Continental biogeographical region indicate how important it is to monitor CLC and ES for potential spatial planning and regional policy interventions.
\end{abstract}

Keywords: ecosystem services; European cities; Corine Land Cover; core city; large urban zone

\section{Introduction}

Ecosystem services (ES) in cities and surrounding suburban areas are one of the factors which guarantee the quality of life in cities [1-7]. However, the population increases in these areas, to the detriment of the natural ecosystems (forests, wetlands) and the agricultural and transformed areas (e.g., green urban areas) which provide numerous ecosystem services. Even if the population decreased in some cities in Europe from 1990 to 2006, the number of households (and the space for housing associated with households) increased [8]. Land use conflicts occur that threaten sustainable use. Between 1990 and 2006 alone, urban areas (in 24 European countries) grew by 146\% [9]. This problem may intensify in the coming years as Europe, where $73 \%$ of the population currently lives in urban areas, is expected to be over $80 \%$ urban by 2050 [10]. Even regions where the population does not increase but urban sprawl develops are threatened, such as in the case of Western and Central Europe, in particular in northeastern France, Belgium, the Netherlands, and part of Western Germany [11]. The consequence of the decreasing surface area of ecosystems within urbanized areas is an automatic weakening of ecosystem services, and therefore a decrease in the quality of life. This problem is particularly important 
in the context of changes occurring in the environment and their impact on human life, with climate change as an example. Consequences of such changes will also impact the functioning of cities. The types of consequences depend on the region. The impact and effects of climate change are diverse, and are more or less negative depending on the region. For example, in the Boreal region in Europe, among others, higher forest growth and higher crop yields may occur, while the Mediterranean region may see lower crop yields and more forest fires. For the Continental (Central and Eastern Europe) biogeographical region, the effects of climate change are: more temperature extremes, less summer precipitation, more river floods in the winter, higher water temperature, higher crop yield variability, increased forest fire danger, and lower forest stability [12] (p. 43). Such regional diversity has also been confirmed in studies about the spatial distribution of urban green space development across European cities [13].

Most studies and publications directly referring to urban ecosystem services (UES) were carried out in Europe, North America, and China [14-16]. They mostly concern regulating ecosystem services [17-31] and cultural ecosystem services [32-37]. Biodiversity is also a frequent object of the studies [27,38-44]. Studies are conducted mostly on a local scale or for selected cities. There are still few studies concerning temporal changes (mostly for the period from 1990 to 2006) in ecosystems and the provision of ecosystem services across a large number of cities $[13,45,46]$. Corine Land Cover 2012 (CLC 2012) gives us an opportunity to observe the changes that took place during the tie period from 2006-2012 [47].

The aim of this paper is to measure the temporal changes of selected ecosystem services for cities from 1990 to 2012, during the intervals of 1990-2000, 2000-2006, and 2006-2012 in the Continental (Central and Eastern) biogeographical region in Europe. Apart from changes in services, changes in biodiversity, selected types of land cover (forest, urban green area), and soil sealing were also studied. By knowing more about the trends in land use changes in the region, we can also predict the ecosystem services changes, because land use has a direct impact on ecosystem services [48,49].

\section{Materials and Methods}

\subsection{Data}

This study looks at 85 large European urban regions with more than 100,000 inhabitants in nine countries located in Western and Central Europe, mainly in Germany, Poland, the Czech Republic, and eastern France (Figure 1). According to the division into biogeographic regions as defined in the EU Habitats Directive, this region is called the Continental region [12,50]. The Continental region also covers a part of the Apennine Peninsula-isolated by the Alps. The southern part of the region is influenced by Mediterranean and Sub-alpine conditions. The Western part of the Continental region is influenced by the Atlantic region (less noticeable contrast between cold winter and warm summer, longer growing season) [51-53]. For the study, cities with similar climate conditions (warm temperate, fully humid, warm summer, strong contrast between cold winter and warm summer), vegetation type (temperate deciduous forest), relief (generally flat, mainly in the Great North European Plain), soils type (Cambisols), and land use (agricultural or mosaic of agricultural and forest) $[12,47,51]$ have been chosen. Cities belonging to the Continental biogeographical region, but located in the southern and western parts, have been excluded. These are: Trieste, Brescia, Milano, Bologna, Venice, Verona, Cremona, Torino, Modena (northern Italy), Ljubljana, Maribor (Slovenia), Bucharest, Cluj-Napoca, Craiova, Bacau, Targu Mures, Piatra Neamt, Giurgiu, Alba Iulia (Romania), Sofia, Plovdiv, Pleven, Ruse, Vidin, Stara Zagora (Bulgaria) and Limoges, Clermont-Ferrand, and Lyon (central France).

The social and economic situation of the countries in this region is diverse. Cities located in the eastern part of Germany, in Poland, and the Czech Republic were subject to processes of social, economic, and political transformation in and after the 1990s. Poland and the Czech Republic were the last countries (analyzed in this research) to join the EU in 2004; therefore, all environmental directives of the EU were implemented last in these countries. 
Urban regions were divided into two zones: the core zone $(C)$ within the administrative borders and the large urban zone (LUZ) which consists of a city and its commuting zone as well as its suburban and rural surroundings. LUZ is composed of local administration units, of various levels, depending on the country. Borders of large urban zones were defined by the Urban Audit [54]. LUZs were applied in the Urban Atlas project and the borders identified on the project website were used [55]. Urban Audit 2004-a project of Eurostat [54], the Statistical Office of the European Union, typically includes cities in Europe with more than 100,000 inhabitants. In several cases, the core zones include a few cities which create a polycentric metropolitan area. They are the Tricity (Gdańsk, Gdynia, and Sopot) and the Silesian Metropolis (Katowice, Bytom, Chorzów, Dabrowa Górnicza, Gliwice, Ruda, Rybnik, Siemianowice, Sosnowiec, Świętochłowice, Tychy, Zabrze, and Żory) in Poland; the Nuremberg Metropolitan Region (Nürnberg, Fürth, Erlangen) and Frankfurt am Main with Offenbach in Germany. For Copenhagen, the core zone also included Frederiksberg, an enclave surrounded by the Copenhagen Municipality. In the case of Wuppertal and Frankfurt (Oder), the borders of the LUZs were identical to the core zones (Figure 1).

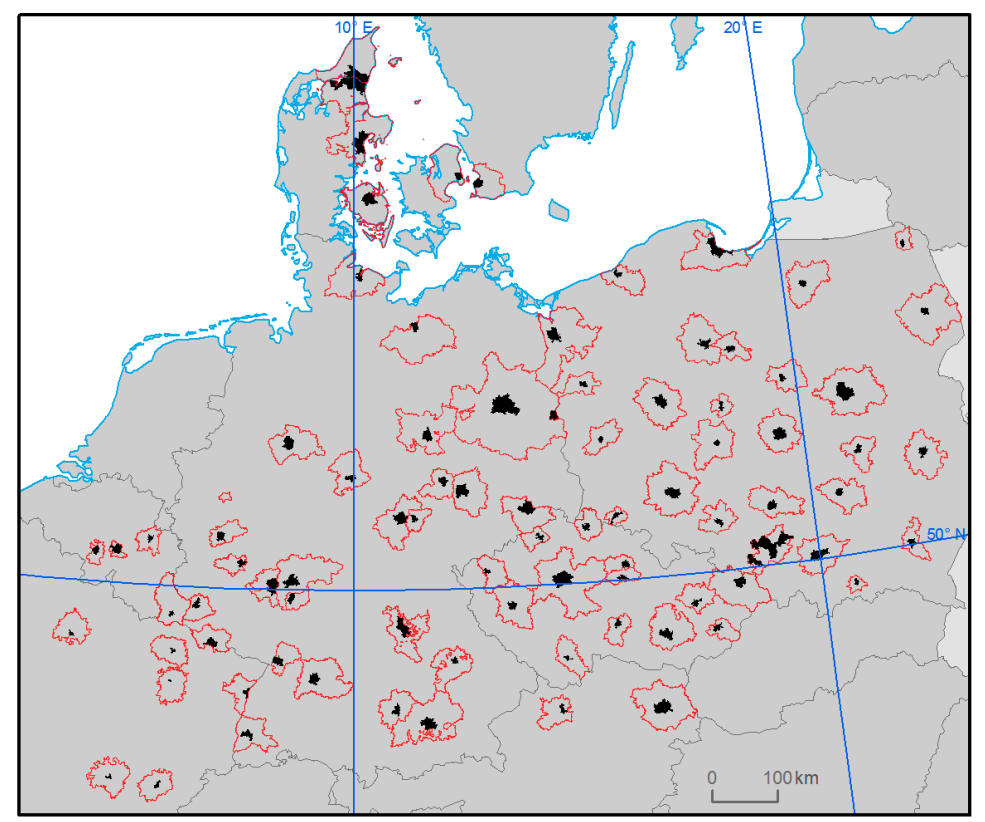

Figure 1. Location of the analyzed cities. Red line—large urban zone (LUZ), black area—core zone (C).

Ecosystem services were based on the Corine Land Cover (CLC) geo-database [56]. It contains an inventory of land cover in 44 classes for most areas of Europe. The first inventory involves the year 1990, and then updates were produced in 2000, 2006, and 2012. For all four products, the following parameters are identical: the mapping scale is 1:100,000, the minimum mapping unit is 25 hectares and the minimum width of linear elements is $100 \mathrm{~m}$. The CLC is produced by a majority of countries by the photointerpretation of satellite images. In a few countries, semi-automatic solutions are applied, using in situ data, satellite image processing, Geographic Information System (GIS) integration, and generalization. For the CLC 1990 inventory, satellite images from 1986 to 1998 were used, and then it was developed based on satellite images from \pm 1 year in relation to the reference year. The thematic accuracy according to technical specifications is more than 85\% [57]. All CLC datasets are freely available at the Copernicus website, of the European Earth Observation Programme [56]. For Malmö, there is data available only from 2000 to 2012, as Sweden was not included in the 1990 mapping. Data was formatted in the Esri Geodatabase vector format. Spatial analyses were performed in the Esri ArcGIS 10.3 and SAGA GIS programs. 


\subsection{Assessment of Ecosystem Services and Biodiversity}

The selection of ecosystem services (ES) depends on the possibilities of estimating them in an indirect manner, based exclusively on data about land cover; in fact, numerous ES are related to land use/land cover (LULC) [13,14,58-60]. An evaluation of the changes in ES was performed by applying methods from other urban areas in Europe [58,59,61,62].

Provisioning Ecosystem Services (food production potential/cultivated crops)—an indicator based on the surface area (ha) of CLC classes directly related to agriculture, i.e., including annual and permanent crops (classes 211,221,222, 241), excluding meadows and agricultural heterogeneous categories (classes 242, 243) and not expected in the Continental biogeographical region (classes 212, 213).

Regulation and Maintenance Services (climate regulation)—-three indicators were selected: surface emissivity, f-evapotranspiration, and carbon sequestration. Surface emissivity is a good proxy for analyzing urban heat stress and temperature contributions. The indicator 'f-evapotranspiration' (f-ETP) captures latent heat flows because the relationship between latent heat and evapotranspiration is linear and is, accordingly, a good complement to the valuation of surface emissivity. Empirical values derived from tables found in the literature $[63,64]$ were used to evaluate the indicators of surface emissivity, f-evapotranspiration, and carbon storage. To obtain values for surface emissivity, a lookup table was used that was created by Schwarz et al. [64]. The set used in that study was derived from a regional thermal analysis conducted for the city of Leipzig (located in the Continental biogeographical region) by creating an index value for different land-use classes considering their thermal emissions (Table 1). The correlation between two indicators used to follow changes within climate regulating services is negative. A high emissivity index is paired with a low evapotranspiration value and vice versa [64].

Carbon storage represents the above-ground C-storage $[\mathrm{MgC} / \mathrm{ha}]$, where for each CLC class, the average value was assumed (Table 1). The value was based on the results of empirical research conducted in the city of Leipzig by Strohbach and Haase [28] and classes which do not occur in Leipzig, according to Gibbs [65].

Cultural Ecosystem Services (Recreation, Mental, and physical health)—indicator based on the surface area and accessibility of recreational areas:

- Recreational areas [ha] — consisted of land-cover classes related to forests (CLC class codes 311, 312 and 313), green urban areas (141 and 142) and water (511, 512, 521, 522 and 523). Within the CLC class 142 "sports and leisure facilities", sealed surfaces (sports facilities with infrastructure) are also included.

- Accessibility of recreational areas [\%]—comprised the share of the category of a recreation center with a buffer of $300 \mathrm{~m}$ around settlements (CLC classes 111, 112)—deemed residential buildings. The regulatory agency English Nature recommends that each person should have green space no further than $300 \mathrm{~m}$ or a 5-min walk from their home [66].

Biodiversity Potential - the biodiversity index is calculated based on the estimated measure of biodiversity on a scale (0-5) for each class of the CLC. The highest rank (5) is assigned to forests and peat bogs, rank 1 to built-up areas, and rank 0 to no vegetation (Table 1). Biodiversity means the presence or absence of selected species, (functional) groups of species, biotic habitat components, or species composition. Biodiversity ranking is an expert-based evaluation which links some aspect of LULC with the potential output of goods and services. Assessment of biodiversity ranks for the CLC classes is based on the study by Burkhard et al. [67] with further rank modifications by the authors. Modifications were made concerning: (a) Artificial surface as an area without vegetation or manmade habitats with non-spontaneous vegetation such as parks, lawns, gardens (reduces the rank by 1 for classes 121, 123, 124, 132, 133, 141, 142; reduces the rank by 2 for classes 122, 131), (b) Wetlands (increases the rank by 2 for 411 , and by 1 to 412, 421, 423) and Water bodies (increases the rank by 1 for classes 522 and 523) as a natural or semi-natural ecosystem. The final value is the weighted average of ranks based on the partial area of a given class. 
Table 1. Indicator values for each Corine Land Cover (CLC) class that were used to calculate the chosen ecosystem services (ES), biodiversity, and soil sealing change.

\begin{tabular}{|c|c|c|c|c|c|c|c|}
\hline $\begin{array}{l}\text { CLC } \\
\text { Code }\end{array}$ & CLC Class & $f$-Value & $\begin{array}{l}\text { Surface } \\
\text { Emission } \\
\text { (Mean) }\end{array}$ & $\begin{array}{l}\text { Carbon } \\
\text { Storage } \\
\text { MgC/ha }\end{array}$ & $\begin{array}{c}\text { Recreation [ha] and } \\
\text { Accessibility of } \\
\text { Recreational Areas [\%] }\end{array}$ & $\begin{array}{l}\text { Degree of } \\
\text { Impervious } \\
\text { Cover }[\%]\end{array}$ & $\begin{array}{c}\text { Biodiversity } \\
\text { Rank }\end{array}$ \\
\hline 111 & Continuous urban fabric & 0.8 & 143.2 & 4.65 & & 95 & 1 \\
\hline 112 & Discontinuous urban fabric & 0.9 & 139.4 & 12.93 & & 60 & 1 \\
\hline 121 & Industrial or commercial units & 0.8 & 141.5 & 8.52 & & 90 & 0 \\
\hline 122 & $\begin{array}{l}\text { Road and rail networks and } \\
\text { associated land }\end{array}$ & 0.8 & 145.1 & 0 & & 60 & 0 \\
\hline 123 & Port areas & 0.8 & 139.9 & 8.52 & & 85 & 0 \\
\hline 124 & Airports & 0.8 & 139.9 & 8.52 & & 85 & 0 \\
\hline 131 & Mineral extraction sites & 1.0 & 137.0 & 0 & & 20 & 0 \\
\hline 132 & Dump sites & 1.0 & 139.0 & 0 & & 20 & 0 \\
\hline 133 & Construction sites & 1.0 & 134.8 & 0 & & 20 & 0 \\
\hline 141 & Green urban areas & 1.1 & 134.3 & 29.38 & yes & 20 & 2 \\
\hline 142 & Sport and leisure facilities & 1.0 & 138.4 & 5.00 & yes & 40 & 1 \\
\hline 211 & Non-irrigated arable land & 1.1 & 138.9 & 5.00 & & 0 & 2 \\
\hline 221 & Vineyards & 1.1 & 141.4 & 16.03 & & 0 & 2 \\
\hline 222 & Fruit trees and berry plantations & 1.1 & 141.4 & 16.03 & & 0 & 2 \\
\hline 231 & Pastures & 1.1 & 135.4 & 4.5 & & 0 & 3 \\
\hline 242 & Complex cultivation patterns & 1.1 & 136.6 & 5.00 & & 0 & 3 \\
\hline 243 & $\begin{array}{l}\text { Land principally occupied by } \\
\text { agriculture, with significant } \\
\text { areas of natural vegetation }\end{array}$ & 1.1 & 135.7 & 5.00 & & 0 & 4 \\
\hline 311 & Broad-leaved forest & 1.1 & 134.0 & 68.31 & yes & 0 & 5 \\
\hline 312 & Coniferous forest & 1.3 & 137.4 & 72.91 & yes & 0 & 5 \\
\hline 313 & Mixed forest & 1.2 & 132.8 & 75.71 & yes & 0 & 5 \\
\hline 321 & Natural grasslands & 1.1 & 135.0 & 4.50 & & 0 & 5 \\
\hline 322 & Moors and heathland & 1.1 & 137.0 & 4.50 & & 0 & 4 \\
\hline 324 & Transitional woodland-shrub & 1.1 & 136.0 & 10.12 & & 0 & 4 \\
\hline 331 & Beaches, dunes, sands & 1.0 & 136.0 & 10.12 & & 0 & 3 \\
\hline 332 & Bare rocks & 1.0 & 139.1 & 0 & & 0 & 3 \\
\hline 333 & Sparsely vegetated areas & 1.0 & 139.1 & 10.12 & & 0 & 3 \\
\hline 334 & Burnt areas & 1.4 & 139.1 & 0 & & 0 & 1 \\
\hline 411 & Inland marshes & 1.4 & 140.4 & 0 & & 0 & 4 \\
\hline 412 & Peat bogs & 1.2 & 140.4 & 0 & & 0 & 5 \\
\hline 421 & Salt marshes & 1.2 & 140.4 & 0 & & 0 & 4 \\
\hline 423 & Intertidal flats & 1.2 & 140.4 & 0 & & 0 & 4 \\
\hline 511 & Water courses & 1.4 & 131.3 & 0 & yes & 0 & 4 \\
\hline 512 & Water bodies & 1.4 & 131.3 & 0 & yes & 0 & 4 \\
\hline 521 & Coastal lagoons & 1.4 & 131.3 & 0 & yes & 0 & 4 \\
\hline 522 & Estuaries & 1.4 & 131.3 & 0 & yes & 0 & 4 \\
\hline 523 & Sea and ocean & 1.4 & 131.3 & 0 & yes & 0 & 3 \\
\hline
\end{tabular}

Also, the share of impervious areas (connected to soil sealing), which is related to numerous urban ecosystem services was quantified using empirical data according to Haase and Nuissl [68], where for each CLC class, the average share of impervious areas was assumed. Furthermore, changes in classes of cover related to forests (CLC class codes 311, 312, and 313) and urban green spaces (141 and 142) were analyzed separately as direct influencers on the numerous ecosystem services and the quality of life of people in cities $[48,49]$. Calculations were made for: six ecosystem services, biodiversity, and three auxiliary indicators based directly on LULC.

\subsection{Assessment of the Rate of Changes for Ecosystem Services and Additional Indicators}

The basic method for analyzing changes was the relative change expressed in percentages for the entire analyzed period of 1990-2012, i.e., a 22-year period. In order to compare changes for the 
three periods of 1990-2000, 2000-2006, and 2006-2012, the annual rate of changes was calculated for each analyzed city and indicator, where the percentage difference was divided by the number of years in each period. For indicators which are not expressed as a percentage (surface emissivity, f-evapotranspiration, carbon storage, biodiversity potential), before calculating the annual rate, value normalization was conducted to establish the minimum and maximum value theoretically possible for a given indicator, e.g., surface emissivity for particular CLC classes is 131.1 for water and 145.1 for roads; therefore, the maximum theoretical value is 145.1 (if the entire city is covered by roads). In the assessment of changes, for no changes, the annual rate was assumed between -0.1 and $0.1 \%$, giving a change of up to $10 \%$ after 100 years. The value of $0.5 \%$ (a change by $50 \%$ after 100 years) can be considered to be a relevant annual rate.

\section{Results}

\subsection{Temporal Changes in the Share of Forests, Green Urban Areas, and Impervious Areas from 1990 to 2012}

In most cases, the share of forest ecosystems in the core and LUZ of the studied cities grew in the 22-year period (1990-2012). The highest growth of forest areas occurred in the last period of 2006-2012. In core zones, coniferous forests dominated and still dominate (currently 51\%), and in the LUZs, deciduous forest growth was observed. Leipzig in Germany reached the highest growth in forest areas in the core zones by $378 \%$, i.e., by 1145 ha. A decrease in forest area was observed in the core zones of 27 cities and in 12 LUZs (Figure 2). The highest percentage loss was observed in Regensburg (-26\%), Metz $(-22.6 \%)$, Linz $(-12.6 \%)$, Nancy $(-11.8 \%)$, and in the LUZs of Płock, Allborg, Reims, and Nancy (approximately $5 \%$ each) (Figure 3).
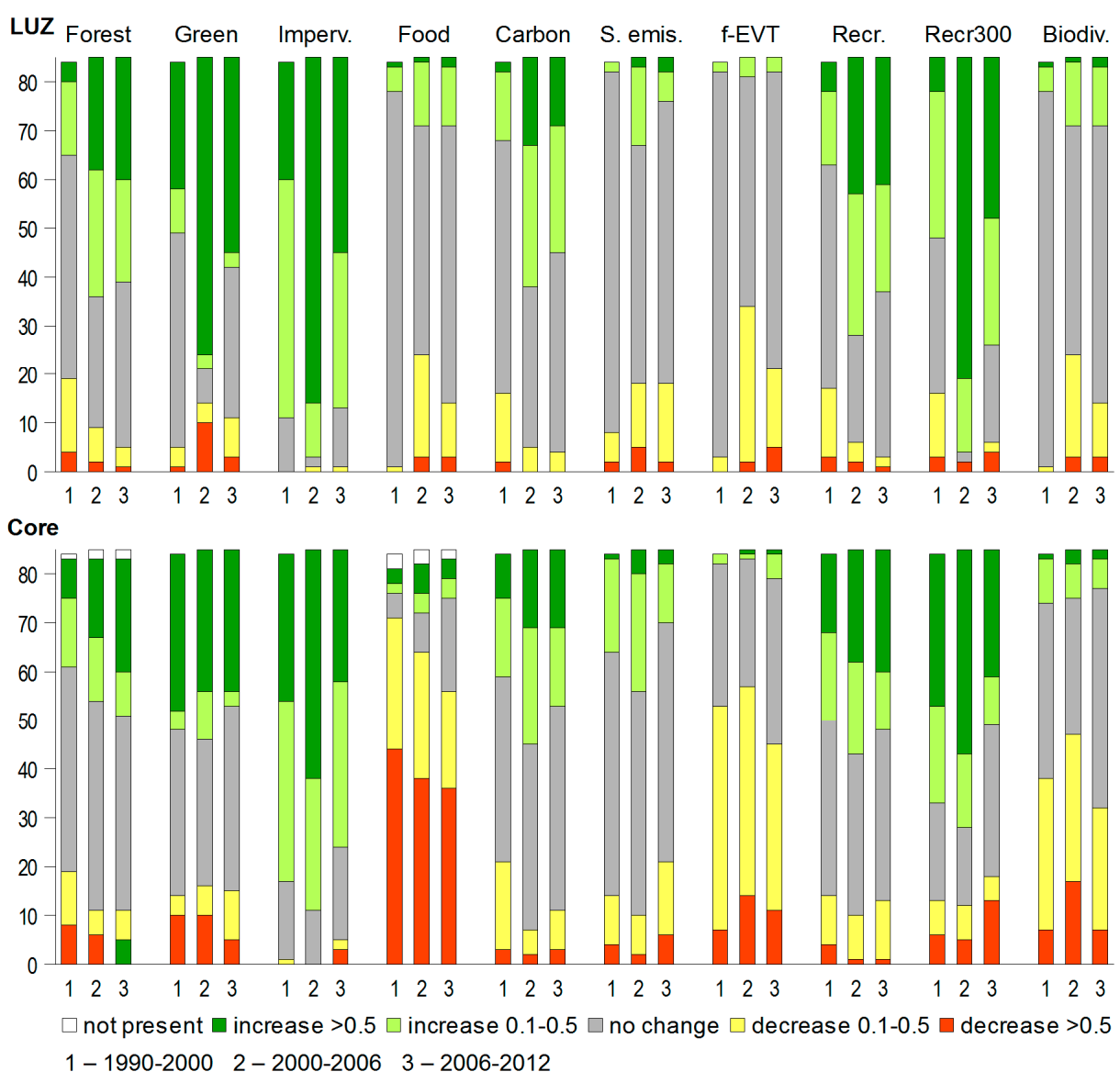

Figure 2. The annual rate of changes [\% per year] for land use, ecosystem services, and biodiversity in 85 cities in the three periods from 1990-2000, 2000-2006, and 2006-2012; nc-no change. 
Besides forest areas, urban green areas increased in surface area in most cities. In 16 core zones, a loss was observed, mostly in Poland. LUZs indicate a greater intensity of changes in urban green spaces. In particular, for the interval from 2000 to 2006, the greatest growth of this type of surface in LUZs was observed to be $0.5 \%$ per year across 61 cities (Figure 2).

Impervious areas had the highest dynamics during the 22-year period (Figure 2). The process of soil sealing growth occurred in all studied cities (except for the core zone of Munich and Liège). Among the analyzed cities of Europe, cities in Poland were characterized by an exceptionally high growth of sealed surfaces, not only in core zones, but also in LUZs (for example Jelenia Góra with 64\% and $182 \%$, respectively) (Figure 3 ).
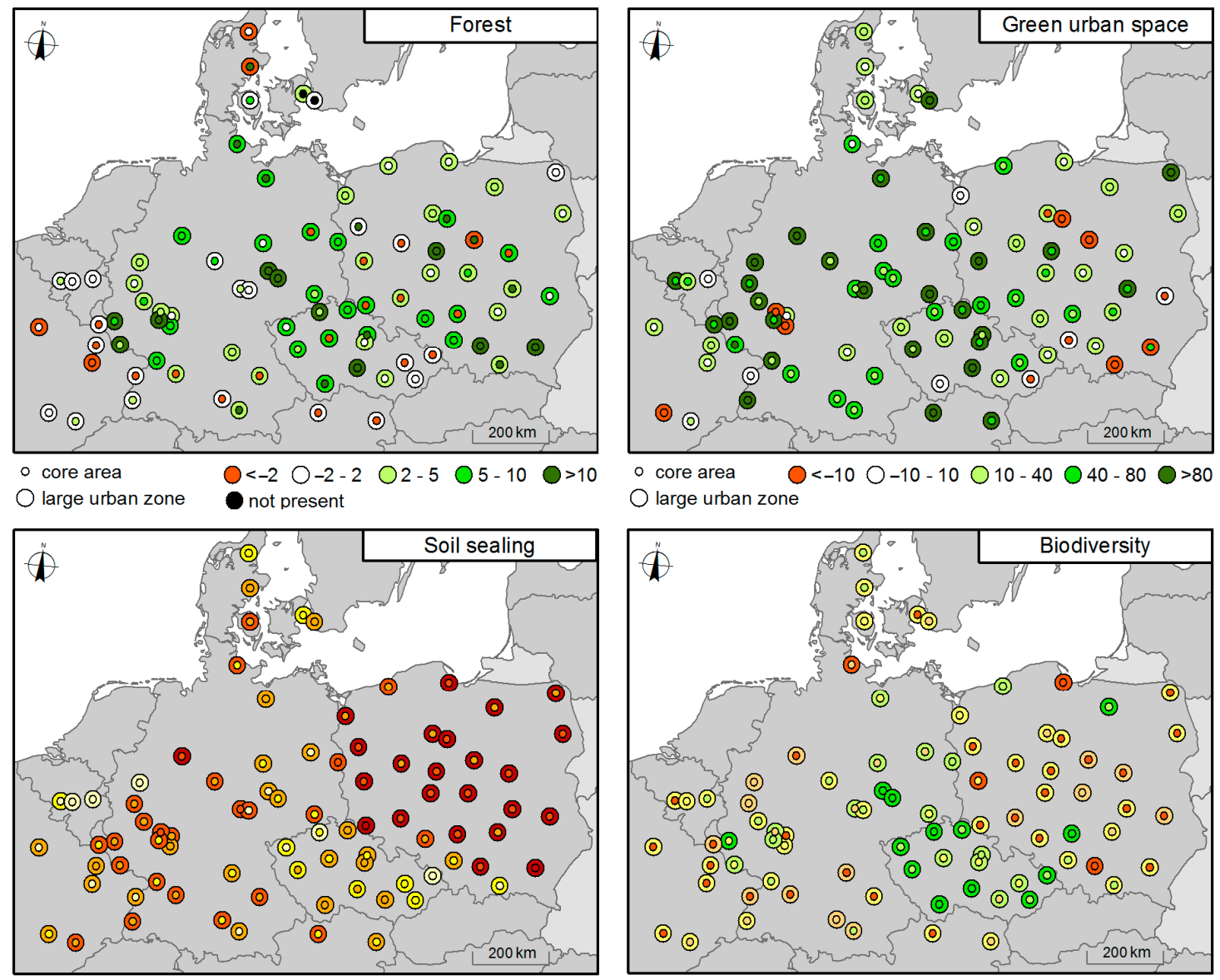

- core area

$\bigcirc<5 \bigcirc 5-10 \bigcirc 10-20 \bigcirc 20-40 \bigcirc>40$

large urban zone large urban zone

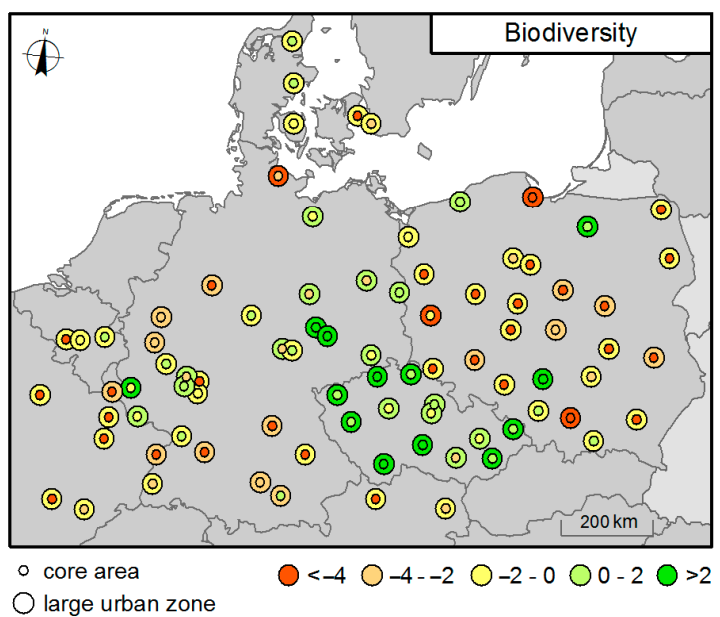

Figure 3. Temporal changes [\%] in green urban spaces, forest area, soil sealing, and biodiversity in 85 cities for the period from 1990 to 2012. The scale for each indicator is adjusted to the range of values of the sample of points.

\subsection{Temporal Changes in Ecosystem Services}

The total area of cultivable/agricultural land and orchards as an indicator of the provisioning ecosystem services (class: cultivated crops) drastically decreased in the period from 1990 to 2012 (Figure 4), especially in the interval from 2006 to 2012 (Figure 2). Among the studied cities, there are cities where there are no agricultural areas in the core area (Besançon and Nancy), or where they constitute approximately half or more of the core area, e.g., cities in Denmark (Aalborg $60 \%$ and Aarhus 49\%), in Poland (Suwałki 46\% and Kalisz 48\%) and in the Czech Republic (Olomouc 50\%). The fastest rate of decrease for the provision of ecosystem services (more than $0.5 \%$ per year) within the borders of the core area was observed between 1990-2000 (43 cities) and within the borders of 
LUZs in 2000-2006 (in 27 cities, mainly in Germany and the Czech Republic) (Figure 2). A decrease in the surface area capable of producing crops outside the core area, i.e., where a city spills, is not a beneficial process from the perspective of there being a limited supply of food from areas located close to the city center, which is significant in the context of carbon footprints.

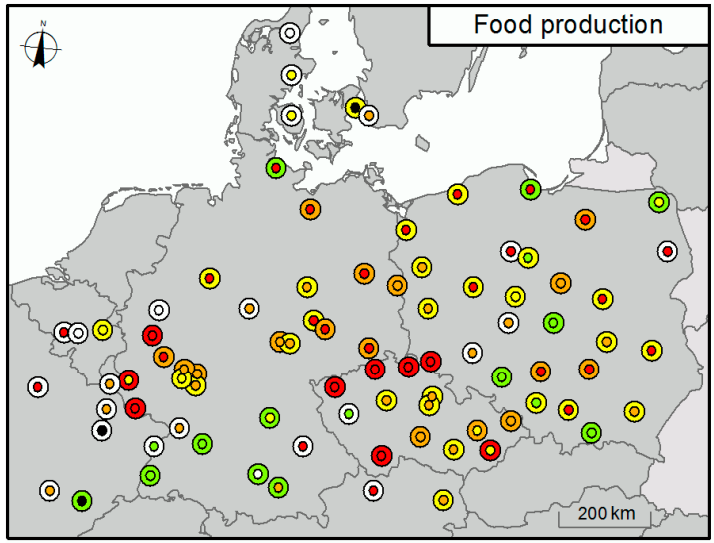

0 core area $\quad 0<-20 \bigcirc-20--10 \bigcirc-10--3 O-3-3 \bigcirc>3$ large urban zone

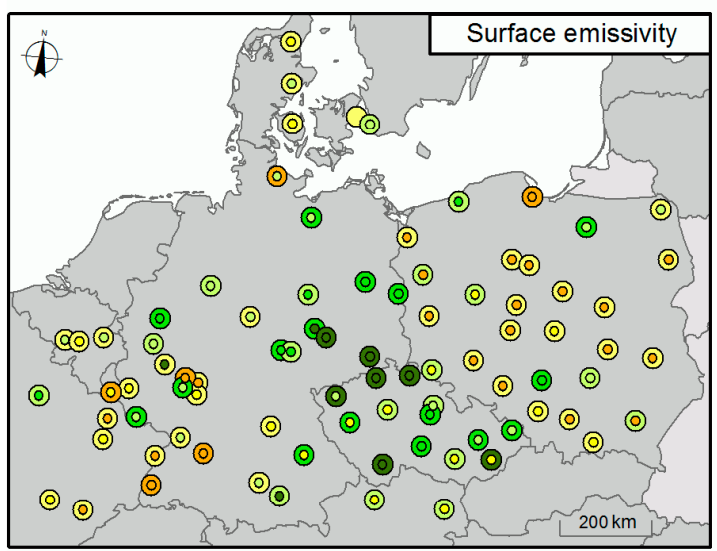

o core area $O<-0.2 \bigcirc-0.2--0.1 \bigcirc-0.1-0.0 \bigcirc 0.0-0.1 \bigcirc>0.1$ O large urban zone

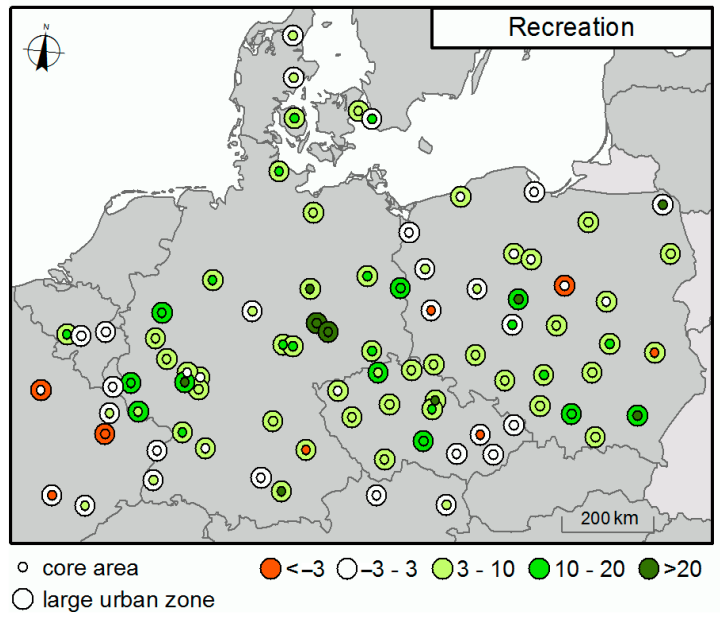

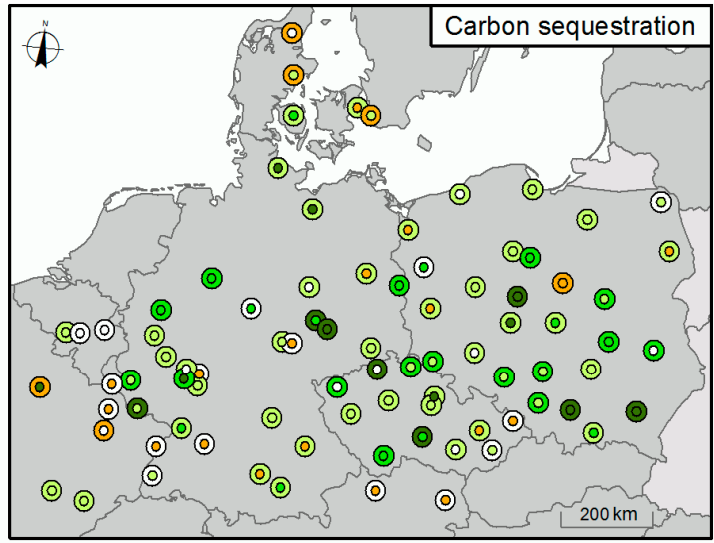

$\circ$ core area $\quad 0<-10-1-1 \quad 01-5 \quad 05-10 \quad \bigcirc>10$ O large urban zone

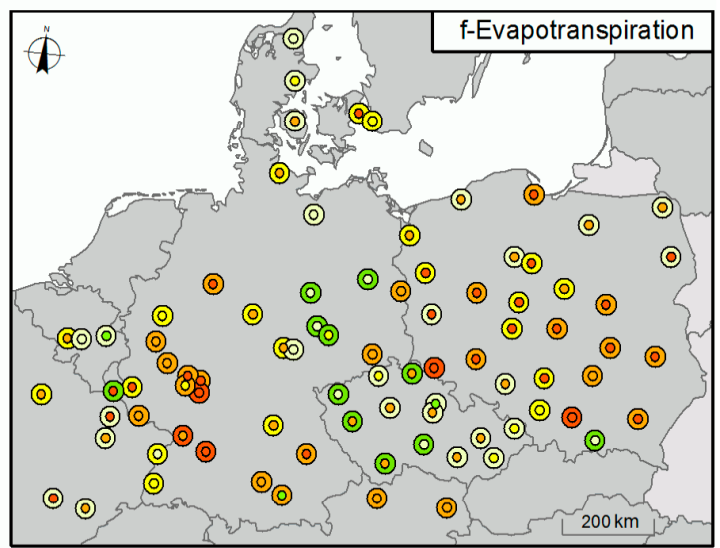

o core area $0<-1.2 \bigcirc-1.2--0.6 \bigcirc-0.6--0.3 \bigcirc-0.3-0.0 \bigcirc>0.0$ O large urban zone

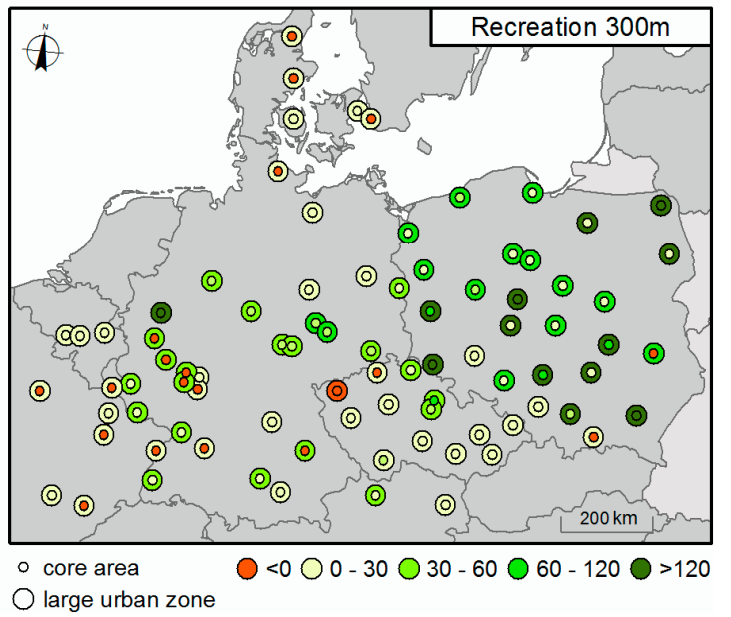

Figure 4. Temporal changes [\%] in food production, carbon sequestration, surface emissivity, f-evapotranspiration, recreation area, and accessibility of recreational areas in 85 cities for the period from 1990 to 2012. The scale for each indicator is adjusted to the range of values of the sample of points. 
Changes within climate regulating ecosystem services are small. F-evapotranspiration in core areas varied from $-3.13 \%$ to $0.35 \%$ and in LUZs from $-1.47 \%$ to $0.63 \%$. This indicator decreased more in the core area of cities in Poland and in LUZ of cities in the western part of Germany (Figure 4) and was related to the increase of soil sealing areas during these years (Figure 3). In the period from 2000 to 2006, the growth rate of impervious surfaces was at its highest and, as can be seen in Figure 2, the rate of evapotranspiration fell. At that time, there was also an increase in the number of cities with an increased emissivity growth rate above $0.1 \%$ per year within the borders of core zones and LUZs (Figure 2).

During the 22-year period, carbon storage did not improve in 10 cities within the borders of LUZs and in 24 cities within the core zones (Figure 4). The minimum value for the core zones was $-6.57 \%$, and the maximum value was $30.33 \%$. The highest growth rate was observed in the period from 2000 to 2006, while in the subsequent years it was stable (Figure 2).

The trends in biodiversity changes are similar in the core areas and in LUZs. A clear growth tendency is observed in cities in the Czech Republic and Germany. The greatest decrease in this indicator-more than 10\%-was observed in the core zones of cities in Poland (Wrocław, Warszawa, Rzeszów, Radom, and Kalisz) (Figure 3). In the period from 2000 to 2006, a majority of cities saw a drop in this indicator (Figure 2).

A very positive trend is the growth of the recreation indicator (above 10\%), observed in most core zones of cities in Germany and several cities in the Czech Republic, Poland, and Denmark (Figure 4). In LUZ, 0.01 to $10 \%$ growth is observed. Only in six cities was a decrease in the indicator observed (mostly in Reims, Płock, Nancy, Aarhus). Also, the rate of change of the accessibility of recreational area indicators, after 2000 and within LUZs in particular, had a positive trend (Figure 2).

\section{Discussion}

The results show that there is not a single city in which clear changes in LULC and ES did not occur. From a historical perspective of a city, a decline or improvement in ES depends on development and the socio-economic system. In recent decades, declines in ES were observed due to industrial and residential development [69].

The most spectacular change concerns impervious areas, with only two cities (Munich, Liège) not showing growth. A high rate of change confirms the intense urbanization process from 2000 to 2006, in particular. A very high rate of growth in impervious areas in cities in Poland is concerning, as this country will become one of the countries (including Belgium, Germany, and France) with high indicators of urban sprawl in the next several years if the current trends hold [11]. In the interval from 2006 to 2012, impervious areas increased slower in comparison to the previous period. In European cities the results showed that it is not the increased number of residents that drive further sealing but rather their lifestyles through an increase in space per capita and lack of awareness of soil importance. The awareness of soil importance is the residents' and investors' ecological (soil) competence so that they are aware of the impact of their actions on the environment. For instance, urban dwellers should consider that higher space demand per capita and private cars contribute to the decline of agriculture areas for food production, green space for recreation, improving climate adaptation, surface water run-off, securing, improvement, and development of habitats for flora and fauna, etc. [70].

The improvements in forest areas have been observed, especially within the borders of LUZs. This reflects a general growth trend in forest areas in all regions of Europe since 1990 [12,45]. In 1990-2012 the improvement in green urban areas, both in core zones as well as in LUZs, in most cities in Germany and the Czech Republic was observed. Considering the rate of change [\% per year] within forests and urban green spaces, it can be expected-as in the case of the elaborations by the European Union [45] - that identical results will not be obtained using various data sources with different mapping units and different resolutions; however, the trend should remain the same.

The agricultural area [ha] has been taken to assess food production. Decline in this ES, particularly within core zones of the studied cities, was observed. However, the interpretation of these findings is 
not so obvious, especially in Europe, where we have mostly intensive farming. As indicated by studies on the trends of the provision of ecosystem services (food production) at the EU level, between 2000 and 2010, a decrease in arable lands (most frequently for built-up areas) did not mean a decrease in crops. More crops for food, feed, and energy were produced ( $+1.5 \%$ per 10 years) on less arable land $(-1.9 \%$ per 10 years) [45].

The regulation of ecosystem services have not changed (or changed a little) in LUZ and the core zones. Other studies from Europe show slightly improvement [45]. The assessment in this study has been done at the EU scale, so this could be the reason for the difference. The significance of the mapping scale, the selection of indicators, and the selection of borders of the studied areas is confirmed by the comparison of trends of the changes in five ecosystem services for the Leipzig-Halle region [61]. The trends of the changes are not identical in each case, but regardless, this elaboration confirmed that the year 2006 brought significant changes.

The monitoring of LULC, ecosystem services, and biodiversity seems to be necessary for regional policies and spatial planning at various levels [2,3,71-74]. Following trends allows planners and policymakers to react to changes sooner. An example might be the negative trend for biodiversity, for core zones especially, in most cities. Considering the EU policy on biodiversity, cities should make it a goal to reverse this trend. Additionally, preparing cities for climate change requires an improvement in the indicators for climate regulating ecosystem services, mainly within the most populated core zones. The presence of recreational areas and their accessibility impacts the quality of life in a city. In the studied cities, the indicator for this service requires improvement in the western part of the region, in particular. Food production is still a service which is disappearing from cities [71]. The coming years will probably bring improvements in this indicator, because currently, exploration of the potential of Urban Agriculture for different policies of the European Community can be found within the Europe 2020 strategy.

The accuracy of the obtained results depends on the quality of the CLC. Despite similar methodology for CLC elaborations in 1990, 2000, 2006, and 2012, the third and fourth editions have a better database. That may result from the fact that to elaborate CLC 1990, satellite images from 1986-1998 were used, and the following editions were elaborated based on satellite images from \pm 1 year in relation to the reference year [47,57]. Some changes within ecosystem services may have resulted not from changes in land cover, but from changes in classification, e.g., a patch of forest classified as a park. Similar situations could have occurred in the case of transitions between types of forests (deciduous, coniferous, and mixed). As a result, particularly high rates of changes for some cities and some indicators require additional verification. Moreover, the accuracy of obtained results depends on an indicator values assigned to each CLC class, based on the studies conducted in Leipzig $[28,58,61,63,68]$. The assessment of ecosystem services requires the development of methods which allow for a more individual approach, e.g., estimating S-emissivity based directly on satellite images with a determination for each pixel separately.

\section{Conclusions}

This study presents a study of changes in selected types of land cover and Ecosystem Services in 85 European cities with a population of over 100,000 residents, located within the Continental biogeographical region, conducted for a 22-year period. The Core area and LUZ of each city were analyzed. In order to include the 1990s in the study, the authors decided to use the Corine Land Cover data for 1990, 2000, 2006, and 2012. The Urban Atlas data is usually recommended for tracking such changes in urbanized areas; however, it only includes data starting from 2006.

Based on the performed analyses of 85 European cities, it was found that temporal changes in LULC are beneficial because forest areas and urban green spaces increased, mostly within LUZs, and was observed in cities in Germany and the western part of the Czech Republic. Temporal changes for impervious areas and also for food production and biodiversity, were not beneficial. The most intense rate of soil sealing occurred in Polish cities. These changes were related to the intensification of the 
urban sprawl process, in particular, in the cities of countries undergoing social, economic, and political changes after 1990, i.e., in Poland and the eastern part of Germany (except for Leipzig, Halle, and Berlin). The interval from 2000 to 2006 was characterized by the highest dynamics of change within core zones as well as within LUZ-increase in soil sealing and improvement in forest areas, green areas, carbon storage, and recreation.

Further monitoring of changes in LULC and ecosystem services, at the local scale in particular, should be based on more accurate data [75,76], i.e., Urban Atlas data which is taken into account in the guidelines for "Mapping and assessment of urban ecosystems and their services" [45].

Author Contributions: Iwona Szumacher and Piotr Pabjanek conceived and designed the experiments; Piotr Pabjanek performed the experiments; Iwona Szumacher and Piotr Pabjanek analyzed the data; Iwona Szumacher wrote the paper.

Conflicts of Interest: The authors declare no conflict of interest.

\section{References}

1. Carlo, L.; Birgit, G.; Jaume, F.; Holger, R.; Vincent, G.; Marie, B.; Anna, G.; Maria, B.; Adrian, J.; Judith, B.; et al. Ensuring Quality of Life in Europe's Cities and Towns; EEA-European Environment Agency: Copenhagen, Denmark, 2009.

2. TEEB-The Economics of Ecosystems and Biodiversity. Available online: www.teebweb.org (accessed on 27 December 2014).

3. Bolund, P.; Hunhammar, S. Ecosystem services in urban areas. Ecol. Econ. 1999, 29, 293-301. [CrossRef]

4. Baró, F.; Chaparro, L.; Gómez-Baggethun, E.; Langemeyer, J.; Nowak, D.J.; Terradas, J. Contribution of ecosystem services to air quality and climate change mitigation policies: The case of urban forests in Barcelona, Spain. AMBIO 2014, 43, 466-479. [CrossRef] [PubMed]

5. Breuste, J.; Schnellinger, J.; Qureshi, S.; Faggi, A. Urban ecosystem services on the local level: Urban green spaces as providers. Ekologia (Bratisl.) 2013, 32, 290-304. [CrossRef]

6. Douglas, I. Urban ecology and urban ecosystems: Understanding the links to human health and well-being. Curr. Opin. Environ. Sustain. 2012, 4, 385-392. [CrossRef]

7. MEA-Millennium Ecosystem Assessment. Ecosystem and Human Well-Being: Current State and Trends; The Millennium Ecosystem Assessment Series; Island Press: Washington, DC, USA, 2005; Volume 1, pp. 795-825.

8. Haase, D.; Kabisch, N.; Haase, A. Endless urban growth? On the mismatch of population, household and urban land area growth and its effects on the urban debate. PLoS ONE 2013, 8, e66531. [CrossRef] [PubMed]

9. Triantakonstantis, D.; Stathakis, D. Examining urban sprawl in Europe using spatial metrics. Geocarto Int. 2015, 30, 10. [CrossRef]

10. Department of Economic and Social Affairs, Population Division (2014). Available online: https://esa.un. org/unpd/wup/publications/files/wup2014-highlights.Pdf (accessed on 28 July 2016).

11. EEA-European Environment Agency. Urban Sprawl in Europe: Joint EEA-FOEN Report; Publications Office: Luxembourg, 2016.

12. EEA-European Environment Agency. Protected Areas in Europe-An Overview. Available online: http:/ / www.eea.europa.eu/publications/protected-areas-in-europe-2012 (accessed on 26 December 2016).

13. Kabisch, N.; Haase, D. Green spaces of European cities revisited for 1990-2006. Landsc. Urban Plan. 2013, 110, 113-122. [CrossRef]

14. Schägner, J.P.; Brander, L.; Maes, J.; Hartje, V. Mapping ecosystem services' values: Current practice and future prospects. Ecosyst. Serv. 2013, 4, 33-46. [CrossRef]

15. Luederitz, C.; Brink, E.; Grall, F.; Hermelingmeier, V.; Meyer, M.; Niven, L.; Panzer, L.; Partelow, S.; Rau, A.-L.; Saski, R.; et al. A review of urban ecosystem services: Six key challenges for future research. Ecosyst. Serv. 2015, 14, 98-112. [CrossRef]

16. Elmqvist, T.; Setälä, H.; Handel, S.N.; van der Ploeg, S.; Aronson, J.; Blignaut, J.B.; Gómez-Baggethun, E.; Nowak, D.J.; Kronenberg, J.; de Groot, R. Benefits of restoring ecosystem services in urban areas. Curr. Opin. Environ. Sustain. 2015, 14, 101-108. [CrossRef] 
17. Haase, D.; Larondelle, N.; Andersson, E.; Artmann, M.; Borgström, S.; Breuste, J.; Gomez-Baggethun, E.; Gren, A.; Hamstead, Z.; Hansen, R.; et al. A quantitative review of Urban ecosystem service assessments: Concepts, models, and implementation. AMBIO 2014, 43, 413-433. [CrossRef] [PubMed]

18. Kuttler, W.; Strassburger, A. Air quality measurements in urban green areas-A case study. Atmos. Environ. 1999, 33, 4101-4108. [CrossRef]

19. Nowak, D.J.; Civerolo, K.L.; Trivikrama Rao, S.; Sistla, G.; Luley, C.L.; Crane, D.E. A modeling study of the impact of urban trees on ozone. Atmos. Environ. 2000, 34, 1601-1613. [CrossRef]

20. Nowak, D.J.; Crane, D.E.; Stevens, J.C. Air pollution removal by urban trees and shrubs in the United States. Urban For. Urban Green. 2006, 4, 115-123. [CrossRef]

21. Nowak, D.J. Institutionalizing urban forestry as a "biotechnology" to improve environmental quality. Urban For. Urban Green. 2006, 5, 93-100. [CrossRef]

22. Georgi, J.N.; Dimitriou, D. The contribution of urban green spaces to the improvement of environment in cities: Case study of Chania, Greece. Build. Environ. 2010, 45, 1401-1414. [CrossRef]

23. Peters, E.B.; McFadden, J.P. Influence of seasonality and vegetation type on suburban microclimates. Urban Ecosyst. 2010, 13, 443-460. [CrossRef]

24. Monteiroa, M.V.; Doicka, K.J.; Handleya, P.; Peace, A. The impact of green space size on the extent of local nocturnal air temperature cooling in London. Urban For. Urban Green. 2016, 16, 160-169. [CrossRef]

25. Manes, F.; Incerti, G.; Salvatori, E.; Vitale, M.; Riccota, C.; Costanza, R. Urban ecosystem services: Tree diversity and stability of tropospheric ozone removal. Ecol. Appl. 2012, 22, 349-360. [CrossRef] [PubMed]

26. Hall, J.M.; Handley, J.F.; Ennos, A.R. The potential of tree planting to climate-proof high density residential areas in Manchester, UK. Landsc. Urban Plan. 2012, 104, 410-417. [CrossRef]

27. Tratalos, J.; Fuller, R.A.; Warren, P.H.; Davies, R.G.; Gaston, K.J. Urban form, biodiversity potential and ecosystem services. Landsc. Urban Plan. 2007, 83, 308-317. [CrossRef]

28. Strohbach, M.W.; Haase, D. Above-ground carbon storage by urban trees in Leipzig, Germany: Analysis of patterns in a European city. Landsc. Urban Plan. 2012, 104, 95-104. [CrossRef]

29. Davies, Z.G.; Edmondson, J.L.; Heinemeyer, A.; Leake, J.R.; Gaston, K.J. Mapping an urban ecosystem service: Quantifying above-ground carbon storage at a city-wide scale. J. Appl. Ecol. 2011, 48, 1125-1134. [CrossRef]

30. McPherson, E.G.; Xiao, Q.; Aguaron, E. A new approach to quantify and map carbon stored, sequestered and emissions avoided by urban forests. Landsc. Urban Plan. 2013, 120, 70-84. [CrossRef]

31. Kuittinen, M.; Moinel, C.; Adalgeirsdottir, K. Carbon sequestration through urban ecosystem services. A case study from Finland. Sci. Total. Environ. 2016, 563, 623-632. [CrossRef] [PubMed]

32. Tyrväinen, L. Economic valuation of urban forest benefits in Finland. J. Environ. Manag. 2001, 62, 75-92. [CrossRef] [PubMed]

33. Seeland, K.; Moser, K.; Scheuthle, H.; Kaiser, F.G. Public acceptance of restrictions imposed on recreational activities in the peri-urban Nature Reserve Sihlwald, Switzerland. Urban For. Urban Green. 2002, 1, 49-57. [CrossRef]

34. Vejre, H.; Jensen, F.S.; Thorsen, B.J. Demonstrating the importance of intangible ecosystem services from peri-urban landscapes. Ecol. Complex. 2010, 7, 338-348. [CrossRef]

35. Cohen, D.A.; Golinelli, D.; Wiliamson, S.; Sehgal, A.; Marsh, T.; McKenzi, T.L. Effects of Park Improvements on Park Use and Physical Activity. Am. J. Prev. Med. 2009, 37, 475-480. [CrossRef] [PubMed]

36. Bjerke, T.; Østdahl, T.; Thrane, C.; Strumse, E. Vegetation density of urban parks and perceived appropriateness for recreation. Urban For. Urban Green. 2006, 5, 35-44. [CrossRef]

37. Bertram, C.; Rehdanz, K. Preferences for cultural urban ecosystem services: Comparing attitudes, perception, and use. Ecosyst. Serv. 2015, 2, 187-199. [CrossRef]

38. Zerbe, S.; Maurer, U.; Schmitz, S.; Sukopp, H. Biodiversity in Berlin and its potential for nature conservation. Landsc. Urban Plan. 2003, 62, 139-148. [CrossRef]

39. Strohbach, M.W.; Lerman, S.B.; Warren, P.S. Are small greening areas enhancing bird diversity? Insights from community-driven greening projects in Boston. Landsc. Urban Plan. 2013, 114, 69-79. [CrossRef]

40. Morimoto, Y. Biodiversity and ecosystem services in urban areas for smart adaptation to climate change: "Do you Kyoto"? Landsc. Ecol. Eng. 2011, 7, 9-16. [CrossRef] 
41. Dallimer, M.; Skinner, A.M.J.; Rouquette, J.R.; Maltby, L.L.; Warren, P.H.; Gaston, K.J.; Irvine, K.N.; Davies, Z.G.; Armsworth, P.R. Biodiversity and the feel-good factor: Understanding associations between self-reported human well-being and species richness. BioScience 2012, 62, 47-55. [CrossRef]

42. Barrico, L.; Azul, A.M.; Morais, M.C.; Coutinho, A.P.; Freitas, H.; Castro, P. Biodiversity in urban ecosystems: Plants and macromycetes as indicators for conservation planning in the city of Coimbra (Portugal). Landsc. Urban Plan. 2012, 106, 88-102. [CrossRef]

43. Cohen, M.; Baudoin, R.; Palibrk, M.; Persyn, N.; Rheine, C. Urban biodiversity and social inequalities in built-up cities: New evidences, next questions. The example of Paris, France. Landsc. Urban Plan. 2012, 106, 277-287. [CrossRef]

44. Kowarika, I.; Buchholza, S.; von der Lippea, M.; Seitz, B. Biodiversity functions of urban cemeteries: Evidence from one of the largest Jewish cemeteries in Europe. Urban For. Urban Green. 2016, 19, 68-78. [CrossRef]

45. Maes, J.; Fabrega, N.; Zulian, G.; Lopes, L.; Vizcaino, M.; Ivits, E.; Polce, C.; Vandecasteele, I.; Mari, I.; Bastos, C.; et al. Mapping and Assessment of Ecosystems and their Services: Trends in Ecosystems and Ecosystem Services in the European Union between 2000 and 2010; Publications Office of the European Union: Luxembourg, 2015.

46. Song, X.; Chang, K.-T.; Yang, L.; Scheffran, J. Change in Environmental Benefits of Urban Land Use and Its Drivers in Chinese Cities. Int. J. Environ. Res. Public Health 2016, 13, 1-21. [CrossRef] [PubMed]

47. Feranec, J.; Soukup, T.; Hazeu, G.; Jaffrain, G. European Landscape Dynamics: CORINE Land Cover Data; CRC Press Taylor \& Francis Group: Boca Raton, FL, USA; London, UK; New York, NY, USA, 2016.

48. Estoque, R.C.; Murayama, Y. Examining the potential impact of land use/cover changes on the ecosystem servces of Baguio city, the Philippines: A scenario-based analysis. Appl. Geogr. 2012, 35, 316-326. [CrossRef]

49. Zhan, J. Impact of Land-Use Changes on Ecosystem Services; Springer: Heidelberg, Germany, 2015.

50. EEA-European Environment Agency. Biogeographical Regions; European Environmental Agency: Copenhagen, Denmark, 2016. Available online: http://www.eea.europa.eu/data-and-maps/data/ biogeographical-regions-europe-3 (accessed on 21 April 2017).

51. Sundseth, K. Natura 2000 in the Continental Region; European Commission: Luxemburg, 2005.

52. Ogrin, D. Long-term air temperature changes in Ljubljana (Slovenia) in comparison Trieste (Italy) and Zagreb (Croatia). Morav. Geogr. Rep. 2015, 23, 17-26. [CrossRef]

53. Martinelli, L.; Matzarakis, A. Influence of height/width proportions on the thermal comfort of courtyard typology for Italian climate zones. Sustain. Cities Soc. 2017, 29, 97-106. [CrossRef]

54. EC-European Commission. Urban Audit-Methodological Handbook; Office for Official Publications of the European Communities: Luxembourg, 2004.

55. EEA-European Environment Agency. Urban Atlas Outline; European Environmental Agency: Copenhagen, Denmark, 2010. Available online: http://www.eea.europa.eu/data-and-maps/data/urban-atlas/urbanatlas-outline/urban-atlas-outline (accessed on 21 April 2017).

56. CORINE Land Cover. 2016. Available online: http://land.copernicus.eu/pan-european/corine-land-cover (accessed on 12 July 2016).

57. EEA-European Environment Agency. CLC2006 Technical Guidelines; Publications Office: Luxembourg, 2007.

58. Larondelle, N.; Haase, D. Urban ecosystem services assessment along a rural-urban gradient: A cross-analysis of European cities. Ecol. Indic. 2013, 29, 179-190. [CrossRef]

59. Larondelle, N.; Haase, D.; Kabisch, N. Mapping the diversity of regulating ecosystem services in European cities. Glob. Environ. Chang. 2014, 26, 119-129. [CrossRef]

60. Su, S.; Xiao, R.; Jiang, Z.; Zhang, Y. Characterizing landscape pattern and ecosystem services value changes for urbanization at an eco-regional scale. Appl. Geogr. 2012, 34, 295-305. [CrossRef]

61. Haase, D.; Schwarz, N.; Strohbach, M.; Kroll, F.; Seppelt, R. Synergies, trade-offs, and losses of ecosystem services in urban regions: An integrated multiscale framework applied to the Leipzig-Halle Region, Germany. Ecol. Soc. 2012, 17, 22. [CrossRef]

62. Rocha, S.M.; Zulian, G.; Maes, J.; Thijssen, M. Mapping and Assessment of Urban Ecosystems and Their Services; EUR 27706 EN; European Union: Brussels, Belgium, 2015. [CrossRef]

63. Schwarz, N.; Bauer, A.; Haase, D. Assessing climate impacts of planning policies-An estimation for the urban region of Leipzig (Germany). Environ. Impact Assess. Rev. 2011, 31, 97-111. [CrossRef]

64. Schwarz, N. Urban form revisited-Selecting indicators for characterising European cities. Landsc. Urban Plan. 2010, 96, 29-47. [CrossRef] 
65. Gibbs, H.K. Major World Ecosystem Complexes Ranked by Carbon in Live Vegetation: An Updated Database Using the GLC2000 Land Cover Product (NDP-017b); University of Wisconsin:: Madison, MI, USA, 2006.

66. Barbosa, O.; Tratalos, J.A.; Armsworth, P.R.; Davies, R.G.; Fuller, R.A.; Johnson, P.; Gaston, K.J. Who benefits from access to green space? A case study from Sheffield, UK. Landsc. Urban Plan. 2007, 83, 187-195. [CrossRef]

67. Burkhard, B.; Kroll, F.; Müller, F.; Windhorst, W. Landscapes' capacities to provide ecosystem services-A concept for land-cover based assessments. Landsc. Online 2009, 15, 1-22. [CrossRef]

68. Haase, D.; Nuissl, H. The urban-to-rural gradient of land use change and impervious cover: A long-term trajectory for the city of Leipzig. J. Land Use Sci. 2010, 5, 123-141. [CrossRef]

69. Santana-Cordero, A.M.; Ariza, E.; Romagosa, F. Studying the historical evolution of ecosystem services to inform management policies for developed shorelines. Environ. Sci. Policy 2016, 64, 18-29. [CrossRef]

70. Artmann, M. Driving forecast of urban soil sealing and constraints of its management-The cases of Leipzig and Munich (Germany). J. Settlements Spat. Plan. 2013, 4, 143-152.

71. MEA-Millennium Ecosystem Assessment. Ecosystem and Human Well-Being: A Framework for Assessment; Island Press: Washington, DC, USA; Covelo, CA, USA; London, UK, 2003.

72. Gómez-Baggethun, E.; Barton, D.N. Classifying and valuing ecosystem services for urban planning. Ecol. Econ. 2013, 86, 235-245. [CrossRef]

73. Niemelä, J.; Saarela, S.-R.; Söderman, T.; Kopperoinen, L.; Yli-Pelkonen, V.; Vare, S.; Kotze, J. Using the ecosystems services approach for better planning and conservation of urban green spaces: A Finland case study. Biodivers. Conserv. 2010, 19, 3225-3243. [CrossRef]

74. Wilkinson, C.; Saarne, G.; Peterson, D.; Colding, J. Strategic spatial planning and the ecosystem services concept-An historical exploration. Ecol. Soc. 2013, 18. [CrossRef]

75. Szumacher, I.; Pabjanek, P. The use of land cover data in ecosystem services assessment. Ekonomia $i$ Środowisko 2014, 51, 172-177.

76. Kandzior, M.; Burkhard, B.; Müller, F. Mapping provisioning ecosystem services at the local scale using data of varying spatial and temporal resolution. Ecosyst. Serv. 2013, 4, 47-59. [CrossRef]

(C) 2017 by the authors. Licensee MDPI, Basel, Switzerland. This article is an open access article distributed under the terms and conditions of the Creative Commons Attribution (CC BY) license (http:/ / creativecommons.org/licenses/by/4.0/). 